dejmowanych tematów, nieobecnych w innych publikacjach z obszaru nauk społecznych. Przemiany systemowe i polityczne uwarunkowania edukacyjnych reform nadal są ważną częścią naszego życia społecznego i rozwoju nauk o wychowaniu w naszym kraju. Zmiany zaproponowane w polskim systemie edukacyjnym już po wydaniu tej książki w 2016 roku wskazują na ciągłą dynamikę przemian i związanych z nimi wyzwań dla pedagogów, uczniów i całego społeczeństwa, trudnych do przewidzenia przez autorów analiz polskiej edukacji i jej wyzwań sprzed zaledwie kilku lat ${ }^{8}$.

Piotr Krakowiak*

\title{
Bibliografia
}

Edukacyjny potencjat religii, red. Jerzy Bagrowicz, Jarosław Horowski. Toruń: Wydawnictwo UMK, 2012.

Motyka, Marcin. „«Sektarianizm» zagrożeniem systemu edukacyjnego w świetle doświadczeń ze Szkocji”. Wychowanie Na Co Dzień 1 (2015): 7-12.

Nalaskowski, Aleksander. Pedagogiczne zwierzatko. Fenomen niewiedzy. Kraków: Wydawnictwo Impuls, 2015.

Różne oblicza edukacji. Instytucje i ich znaczenie edukacyjne w zmieniającym się świecie, red. Jarosław Korczak, Błażej Przybylski. Toruń: Adam Marszałek, 2016.

\section{Ewa Ogrodzka-Mazur, Grzegorz Błahut, Teresa Bogusława Chmiel (red.), Wspótczesne ojcostwo. Konteksty kulturowe, peda- gogiczne i prawne, Toruń: Dolnośląska Szkoła Wyższa (Cieszyn), Wydawnictwo Adam Marszałek, 2016, s. 201.}

DOI: http://dx.doi.org/10.12775/PCh.2016.036

Zagadnienia składające się na treść omawianej publikacji zostały zawarte w trzech częściach. 1) Społeczno-kulturowe aspekty ojcostwa. W poszuki-

${ }^{8}$ Por. Witold Kołodziejczyk, Marcin Polak, „Jak będzie zmieniać się edukacja? Wyzwania dla polskiej szkoły i uczniów”, http://www.instytutobywatelski.pl/wp-content/uploads/2011/11/edukacja_kolodziejczyk-polak_internet.pdf (dostęp: październik 2016).

* Ks. dr hab. Piotr Krakowiak jest kierownikiem Katedry Pracy Socjalnej na Wydziale Nauk Pedagogicznych Uniwersytetu Mikołaja Kopernika w Toruniu. Adres: Wydział Nauk Pedagogicznych UMK, ul. Lwowska 1,87-100 Toruń; e-mail: pkrakow@umk.pl. 
waniu tożsamości współczesnego ojca (Anna Dudak, „Wizerunek współczesnego mężczyzny w roli ojca”, 13-23; Teresa Bogusława Chmiel, „Kastrowane ojcostwo. W poszukiwaniu tożsamości współczesnego ojca", 24-38; Karolina Ścigała, Mieczysław Pokorski, „Postawy i style wychowawcze rodziców a zachowanie przestępcze dzieci w dorosłym życiu”, 39-48; Daniela Rajniaková, „Analysis of the man-father's role after material breakup (exemplified by shared custody)", 49-62); 2) Ojciec i dziecko - prawo a rzeczywistość (Dariusz Szenkowski, „Zagubiony wymiar »dobra dziecka« w sądach rodzinnych. Prawne i pozaprawne przyczyny niskiej jakości prawa rodzinnego", 65-92; Marcin Sokołowski, „Prawo ojca do kontaktów z dzieckiem po rozstaniu rodziców w prawie polskim i europejskim", 93-107; Anna Szczepaniak, Rafał Szczepaniak, „Czynniki determinujące pozycję procesową ojca w sprawach o powierzenie wykonywania władzy rodzicielskiej”, 108-124; Agnieszka Ogrodnik-Kalita, „Prawo ojca do uznania ojcostwa dziecka martwo urodzonego", 125-141); 3) Psychologia i teologia ojcostwa (Henryk Krysteczko, „Ojcem być i stawać się”, 145-161; Alojzy Drożdż, „Ojciec z autorytetem pilnie poszukiwany”, 162-180; Natalia Maria Ruman, „Człowiek w obliczu ojcostwa Boga - sens życia i śmierci”, 181-195). Całość dopełniają wprowadzenie (7-10), indeks nazwisk (196-197), noty o autorach (198-201).

Książka wpisuje się we wciąż wzrastające w naszym kraju zainteresowanie problematyką ojcostwa oraz społecznym funkcjonowaniem współczesnych ojców, co potwierdza zebranie kilkunastu tematów w zakresie nauk humanistycznych i społecznych, a także bogata „bibliografia ojcostwa” towarzysząca poszczególnym artykułom. W przedstawieniu obrazu współczesnego ojcostwa pozwolą części ustalone przez redaktorów książki.

1. Wskazuje się na trzy zasadnicze obrazy współczesnego mężczyzny w roli ojca. Jest to „ojciec nieobecny” w życiu dziecka, który nie pełni istotnej roli w wychowaniu dziecka. Jego nieobecność można wythumaczyć pracą, często oddaloną od miejsca zamieszkania, tradycyjnym podziałem ról i zadań domowych lub wynika ona $\mathrm{z}$, braku posiadania modelu funkcjonowania mężczyzny w relacjach z dzieckiem" (s. 14-15). Okazuje się, że przyczyn kryzysu ojcostwa, swoistego „zdezorganizowania mężczyzny”, można wymienić kilkanaście; co więcej dotyczą one także wizerunku kobiety-matki. Oto one: procesy industrializacji i urbanizacji, aktywność zawodowa kobiet, ruchy feministyczne, bunt młodych przeciw autorytetowi starszych, rozwój psychoanalizy, rozwój wolnych związków i innych alternatywnych form życia małżeńskiego, zakwestionowanie duchowości człowieka, obecność systemów totalitarnych, które niszczą morale i psychikę mężczyzn, konflikty zbrojne, 
które separują mężczyzn od rodziny i rodzą trudności adaptacyjne, ewolucja prawodawstwa dążąca w kierunku dyskryminacji mężczyzn, skandaliczne podważanie roli ojca w procesie prokreacji (moje dziecko - mój brzuch), antykoncepcja, która prowadzi obojga do wyzucia się z odpowiedzialności, brak wzorów męskich i ojcowskich w procesie wychowania, brak wychowania do ojcostwa (także do macierzyństwa) (s. 29-30). Brak ojca w wychowaniu dzieci współautorzy książki podkreślają dość często (s. 15-16, 32, 151).

Drugi obraz współczesnego mężczyzny jako ojca to „ojciec zagubiony”. Przyczyna zagubienia tkwi w mężczyźnie dość głęboko i od początku: „często nie ma odpowiedniego wzorca z własnego dzieciństwa" (s. 16), następnie w zachwianiu jego pozycji w wyniku podjęcia pracy zawodowej przez żonę, w zachowaniu matek, które traktują ,macierzyństwo jako rodzaj przewagi nad mężczyznami, często nie dopuszczają ich do czynności związanych $\mathrm{z}$ opieką nad dzieckiem, poddając w wątpliwość kompetencje wychowawcze" (s. 17), a także w tradycyjnym modelu podziału zadań w małżeństwie i rodzinie, który „,zubaża emocjonalny rozwój mężczyzn i utrudnia ich spełnianie się w roli ojca" lub w wytwarzaniu dystansu wobec dziecka ,z powodu męskiego lęku przed ujawnieniem siebie, obawiają się pokazać, co czują i czego pragną”, nadto „trzeba umieć dawać i wspierać, do czego mężczyźni nie są na ogół przygotowani” (s. 17). Przede wszystkim prawidłową postawę ojca wobec dziecka i żony oraz żony wobec męża niszczy lęk przed rodzicielstwem, którego podstawę stanowią brak w przyjęciu, akceptacji i realizacji życia płciowego. Tak pisze o tym w jednej ze swych publikacji Karol Meissner OSB:

Wydaje się, że w obrazie siebie mężczyzny przeważa przeżywanie relacji mężczyzna-kobieta. Oznacza to, że model męskości kształtowany jest głównie w odniesieniu do relacji mężczyzna-kobieta, a nie w odniesieniu do funkcji rodzicielskiej, czyli do relacji ojciec-dziecko. Przedmiotem troski, a nawet pewnego rodzaju lęku, jest to, co fizycznie różni mężczyznę i kobietę. Można to określić mianem niepokoju związanego z płciowym zróżnicowaniem ciała. Wyrazem tego niepokoju są liczne publikacje tzw. uświadamiające i programy tzw. wychowania seksualnego, w których daje się zauważyć skoncentrowanie autora na szczegółach dotyczących budowy ciała i stosunku seksualnego, podczas gdy funkcja rodzicielska, a więc w najściślejszym znaczeniu płciowa, ukazana jest jako zagrożenie dla działających seksualnie, którą albo trzeba odsunąć, albo się przed nią bronić czy zabezpieczyć - jak przed chorobą. Takie ujmowanie prowadzi do okaleczenia doświadczenia męskości przez przeciwstawienie jej relacji rodzicielskiej. Model męskości utworzony na podstawie ta- 
kiej lękowej postawy zupełnie nie odpowiada potrzebom dziecka. Nietrwałość współczesnych małżeństw przemawia też za tym, że sama relacja mężczyzna-kobieta, kształtowana na podstawie takiego nasyconego lękiem modelu męskości, nie może się przekształcić w harmonijną relację mąż-żona. W pewnym sensie nie ma nic w tym dziwnego. Relacja mężczyzna-kobieta jest bowiem powszechna w życiu społecznym i kształtuje w wieloraki sposób życie wszystkich członków społeczności. Wyrazem niedojrzałości zarówno mężczyzny, jak i kobiety, jest jednak to, jeśli nie są w pełni świadomi, że z natury rzeczy jest ona podstawą dla relacji mąż-żona. Trudno mówić o dorosłości mężczyzny i kobiety, jeśli nie są oni świadomi, że relacja ta w swej istocie jest płciowa, a więc że na relację mężczyzna-kobieta, jeśli te osoby podejmują stosunki płciowe, może się nałożyć relacja ojciec-matka, a co za tym idzie - relacja ojciec-dziecko i matka-dziecko'.

Na szczęście wizerunek ojca zagubionego traci coraz bardziej na wartości na korzyść trzeciego obrazu ojca zaangażowanego, to znaczy: 1) zainteresowanego wychowaniem i opieką nad dzieckiem, 2) opowiadającego się za „zrównoważonym rodzicielstwem”, „dwurodzicielstwem od poczęcia” lub „odradzaniem się ekologicznego modelu rodziny”2, 3) zdolnym do podjęcia „samotnego ojcostwa" lub walki o swoje miejsce w życiu dziecka po rozwodzie (s. 18-19, 28, 36). Niezwykle ważne w artykule Teresy B. Chmiel jest stwierdzenie, że „kryzys ojcostwa nierozerwalnie łączy się z kryzysem macierzyństwa" i choć to jest tak oczywiste, to jednak wcale się tego nie podkreśla. Niewątpliwie, na przeszkodzie stoi wszechwładny w pedagogice feminizm, a może bardziej dosadnie: feminokracja. Jak zatem ochronić ojca i minimalizować procesy wykluczania mężczyzn-ojców z życia dzieci? Z pewnością podkreślenie roli ,edukacji z zakresu socjalizacji pierwotnej, przygotowującej do pełnienia określonych ról w rodzinie i w społeczeństwie" (s. 36) może gwarantować wychowanie do ojcostwa, a tym samym udane dzieciństwo dzieci i ich dobry start w przyszłość.

2. Część druga poświęcona jest zagadnieniom prawnym związanym z negatywnymi doświadczeniami życia rodzinnego, a mianowicie rozpadem rodziny: prawu do obecności ojca w wychowywaniu dziecka, prawu ojca

${ }^{1}$ Karol W. Meissner, „Ojciec - potrzeby dziecka a wzorzec męskości”, w: Oblicza ojcostwa, red. Dorota Kornas-Biela (Lublin: TN KUL, 2001), 197-198.

${ }^{2}$ Włodzimierz Fijałkowski, „Dwurodzicielstwo od poczęcia. Ojcostwo w kształtowaniu się nowego modelu człowieka”, w: Oblicza ojcostwa, red. Dorota Kornas-Biela (Lublin: TN KUL, 2001), 285-286. 
do wychowywania dziecka oraz poświadczenia ojcostwa w sytuacji śmierci dziecka. Autorzy zawartych w tej części opracowań wskazują na istniejące w prawie niejasności, które niszczą zamiast budować. Tak jest na przykład w klauzuli dobra dziecka, która ,jest najważniejszą dyrektywą czy zasadą kierunkującą procedowanie sądu rodzinnego" (s. 71). Jest to, jak wykazuje autor tekstu „Zagubiony wymiar »dobra dziecka« w sądach rodzinnych. Prawne i pozaprawne przyczyny niskiej jakości prawa rodzinnego", jedna z wielu „klauzul odsyłających” stosowanych w prawie, które przybierają formę „niedookreślonych zwrotów prawnych” (tak zwanych „klauzul generalnych") po to, by poprzez stosowanie tych niedookreślonych znaczeniowo zwrotów wspomagać podmiot stosujący prawo „do różnych pozaprawnych ocen moralnych, społecznych, ekonomicznych czy politycznych" (s. 68, $96,110)$. Opierając się na bogatym materiale dowodowym tak stosowania prawa polskiego, jak europejskiego, sugeruje potrzebę zdefiniowania, by w miejsce „dostatecznej elastyczności” wypracować określenie „dobra dziecka" (s. 84-85). Pozwoli ono na to, jak wskazuje autor, przywołując judykaturę Sądu Najwyższego (s. 87-88), by rozwód rodziców dziecka nie stawał się przesłanką możliwości ograniczenia przez sąd władzy rodzicielskiej (praw rodzicielskich) jednego z rodziców.

Niestety, zasada równorzędności praw ojca i matki oraz szeroko rozumiana „ochrona życia rodzinnego" w prawodawstwie nie jest respektowana; mówi się o tak zwanej asymetrycznej pozycji matek i ojców w postępowaniach rozwodowych i opiekuńczych (s. 86). Tekst Marcina Sokołowskiego, przywołujący orzecznictwo europejskich Trybunałów, wpisuje się w nurt uzasadnień prawa ojców biologicznych do kontaktu z dziećmi „,niezależnie od innych okoliczności wywiedzionych z prawodawstwa krajowego" (s. 102):

Prawo do wzajemnych kontaktów rodziców i dzieci stanowi niejako rewers i awers tej samej monety, którymi są zasada dobra dziecka oraz zasada poszanowania życia rodzinnego, znajdujące swoje odbicie w Konwencji ONZ o Prawach Dziecka z 1989 roku oraz Europejskiej Konwencji o Ochronie Praw Człowieka i Podstawowych Wolności z 1950 roku. Na gruncie prawa Unii Europejskiej dwuaspektowość tego zagadnienia uwidacznia się w art. 24 Karty Praw Podstawowych [...], a także w szeregu szczegółowych przepisów rozporządzenia unijnego 2201/2203, które potwierdza tę tezę (s. 104).

„Trudno jednak zaprzeczyć istnienia pewnego stereotypu - podkreślają autorzy kolejnego artykułu - a więc swego rodzaju przeświadczenia, że pozycja procesowa ojca w sprawach o powierzenie wykonywania władzy 
rodzicielskiej jest słabsza od pozycji procesowej matki” (s. 109). Pozostanie dziecka przy matce w wyniku rozpadu związku nie musi być uzasadnione przekonaniem, że zapewni ona w większym stopniu niż ojciec realizację zasady dobra dziecka. Sprawa jest tym bardziej trudna, że dochodzi do nagromadzenia zarzutów, które ,przybierają wręcz wymiar totalny” i przedstawiają bardzo negatywny obraz ojca, także wtedy, gdy te zarzuty nie potwierdzają się (s. 113), a tego rodzaju postępowania karne, wszczynane na skutek doniesień, mogą trwać miesiące, a nawet lata. Co więcej, zachowania matki niekoniecznie pociągają za sobą skutki prawne dla niej niekorzystne. Jest też i tak, że ,ustawodawca dał sądowi opiekuńczemu moc rozstrzygania [...], ale nie wskazał kryteriów, w oparciu o które ma zapaść to rozstrzygnięcie" (s. 115-116). Analiza różnych sytuacji prowadzi do stwierdzenia, że zazwyczaj w tych sprawach mamy do czynienia ze schematem działania, które polega na praktycznym uprzywilejowaniu matki, a nie na zwróceniu uwagi na spoczywający na sądzie ciężar nadrzędnego obowiązku, którym jest ochrona dobra dziecka. Nikt zresztą nie pyta dziecka, czy chce pozostać z osobą ubiegającą się o prawa wykonywania władzy rodzicielskiej (s. 118, 121-122).

3. Na uwagę w części trzeciej zasługuje tekst poświęcony autorytetowi ojca. Nie oznacza to, że pozostałe nie mają wartości. Traktuję je jako eseje na temat ojcostwa. Jest on ważny z tego względu, że samo zagadnienie podejmowane jest rzadko, a ponadto żyjemy w czasach niekorzystnych dla autorytetu. Żyjemy w społeczeństwie o pogłębiającym się indywidualizmie i wycofaniu w sferę prywatności. To prawda, że w społeczeństwie wchodzącym w fazę ponowoczesności dochodzi do głosu postawa zakwestionowania autorytetów, ale też jesteśmy świadomi, że są one uznawane nie dla nich samych, tylko o tyle, o ile dają wiarygodne i życiowe odpowiedzi na problemy ważne dla jednostki: „Język ludzki zna dwie formuły wyrażające istnienie autorytetu: «mieć autorytet» $\mathrm{i}$ «być autorytetem» [...] odzwierciedlają one różne stopnie zespolenia z wartościami osobowymi” (s. 167). W chrześcijaństwie autorytet ojca i ojcostwo ojca związane są z autorytetem i ojcostwem Boga. Z kolei mąż i ojciec jest powołany do tego, by rodzina mogła doświadczać prawdy o ojcostwie Boga Ojca, źródła ojcostwa:

Wymownym potwierdzeniem tych związków między ojcostwem ludzkim i Bożym jest fakt, że ci wszyscy, którzy kwestionują rolę, potrzebę oraz znaczenie ojca w rodzinie i społeczeństwie, na ogół kwestionują ojcostwo Boże. I na odwrót: ci, którzy odrzucają Boga jako ojca, często przekreślają wartość ojcostwa ludzkiego, negując przede wszystkim jakiekolwiek związki miedzy jednym a drugim (s. 169). 
Autor tekstu „Ojciec z autorytetem pilnie poszukiwany” przytacza cytat $\mathrm{z}$ adhortacji Familiaris consortio poświęcony spełnianiu się mężczyzny jako odpowiedzialnego ojca. Wydaje się, że zawiera on także wskazanie, w jaki sposób można stać się autorytetem:

Spełni to zadanie przez wielkoduszną odpowiedzialność za życie poczęte pod sercem matki, przez troskliwe pełnienie obowiązków wychowania, dzielonego ze współmałżonką, przez pracę, która nigdy nie rozbija rodziny, ale utwierdza ją w spójni i stałości, przez dawanie świadectwa dojrzałego życia chrześcijańskiego, które skutecznie wprowadza dzieci w żywe doświadczenie Chrystusa i Kościoła (nr 25).

Autorytet, termin przejęty z łaciny, oznacza wpływ, powagę, znaczenie, władzę, sprawczość, a także: pomnożyciel, twórca, doradca, autor (s. 166). Właściwości, którym winien odpowiadać odpowiedzialny ojciec z tekstu adhortacji, odpowiadają w pełni znaczeniu związanemu ze słowem ,,autorytet". Oczywiście, autorytet się zdobywa, choć pełnienie pewnych funkcji zakłada posiadanie autorytetu oraz zgodę na respektowanie autorytetu. Alojzy Drożdż pisze o potrzebie kształtowania i rozwijania w sobie autorytetu, wyjaśnia na czym ma to polegać oraz wskazuje na cechy dojrzałej osobowości, która stanowi fundament autorytetu (s. 171-173).

Zainteresowanie miejscem i rolą ojca $\mathrm{w}$ rodzinie jest niewątpliwie wynikiem bolesnego doświadczenia współczesnego człowieka, który żyje w społeczeństwie bez ojca, w oparach socjalistycznego mitu wspólnoty równoprawnych członków społeczeństwa, gdzie dotychczasowa hierarchiczna relacja ojca z synem powinna być zastąpiona przez emancypacyjną zasadę braterstwa. David Blankenhorn, autor głośnej książki Fatherless America (Ameryka pozbawiona ojców, New York 1995), wykazuje, że wieloraki brak ojca nie tylko stał się największym problemem społecznym Ameryki naszych czasów, ale i obala tezę, jakoby ojcowie nie byli ważni i potrzebni. Pokazuje, jak bardzo kultura nas okłamała, próbując udowodnić, że ojcowie nie są już potrzebni.

Marek Marczewski*

* Dr hab. Marek Marczewski, prof. WSSE, jest profesorem w Wyższej Szkole Społeczno-Ekonomicznej w Gdańsku. Adres: Wyższa Szkoła Społeczno-Ekonomiczna w Gdańsku, ul. Rajska 6, 80-850 Gdańsk; e-mail: mamarcz@wp.pl. 